\title{
Effects of the Popular Food Additive Sodium Benzoate on Neural Tube Development in the Chicken Embryo
}

\section{Yaygin Olarak Kullanılan Gida Katkı Maddelerinden Sodyum Benzoatın Tavuk Embriyosunda Nöral Tüp Gelişimi Üzerine Etkileri}

\author{
Selin TURAL EMON ${ }^{1}$, Metin ORAKDOGEN ${ }^{1}$, Serap USLU ${ }^{2}$, Hakan SOMAY ${ }^{1}$ \\ ${ }^{1}$ Haydarpasa Numune Training and Research Hospital, Department of Neurosurgery, Istanbul, Turkey \\ ${ }^{2}$ Acibadem University, Vocational School of Health Services, Department of Histology and Embryology, Istanbul, Turkey
}

Corresponding Author: Selin TURAL EMON / E-mail: turalselin@gmail.com

\begin{abstract}
AIM: Many more additives have been introduced with the development of processed foods. Neural tube defects are congenital malformations of the central nervous system. More than 300000 children are born with neural tube defects every year and surviving children remain disabled for life. Sodium benzoate is used intensively in our daily lives. We therefore aimed to evaluate the effects of sodium benzoate on neural tube defects in chicken embryos.

MATERIAL and METHODS: Fertile, specific pathogen-free eggs were used. The study was conducted on five groups. After 30 hours of incubation, the eggs were opened under $4 x$ optical magnification. The embryonic disc was identified and sodium benzoate solution was injected. Eggs were closed with sterile adhesive strips and incubation was continued till the end of the 72nd hour. All eggs were then reopened and embryos were dissected from embryonic membranes and evaluated histopathologically.

RESULTS: We found that the development of all embryos was consistent with the stage. We detected neural tube obstruction in one embryo. Neural tube defects were not detected in any embryos.

CONCLUSION: This study showed that sodium benzoate as one of the widely used food preservatives has no effect to neural tube defect development in chicken embryos even at high doses.
\end{abstract}

KEYWORDS: Chicken embryo, Food additives, Neural tube defect, Sodium benzoate

öz

AMAÇ: İ̧̧lenmiş gıdaların gelişimi ile birlikte hayatımıza daha fazla katkı maddesi girmiştir. Nöral tüp defektleri santral sinir sisteminin konjenital malformasyonlarıdır. Her yıl, 300 000'den fazla çocuk nöral tüp defekti ile doğar, yaşayanlar ise engelli olarak hayatlarına devam ederler. Sodyum benzoat günlük hayatımızda yoğun olarak kullanılmaktadır. Biz de bu verilerin bir sonucu olarak tavuk embriyolarında nöral tüp defekti gelişimi üzerine sodyum benzoatın etkilerini değerlendirmeyi amaçladık.

YÖNTEM ve GEREÇLER: Döllenmiş, spesifik patojensiz yumurtalar kullanıldı. Çalışma beş grupdan oluşuyordu. Enkübasyondan 30 saat sonra yumurtalar 4x optik büyütme altında açıldı. Embriyonik disk tespit edildi ve sodyum benzoat solüsyonu enjekte edildi. Yumurta steril bantlar ile kapatıldı ve 72. saate kadar beklenildi. Sonra, bütün yumurtalar tekrar açıldı ve embriyolar embriyonik membrandan disseke edilerek çıkartıldı ve histopatolojik olarak incelendi.

BULGULAR: Bütün embriyoların gelişimleri bulundukları evre ile uyumlu bulundu. Yalnızca bir embriyoda nöral tüp tıkanıklığı tespit edildi. Embriyolarda nöral tüp defekti tespit edilmedi.

SONUÇ: Çalışma, yaygın olarak kullanan gıda koruyucularından biri olan sodyum benzoatın civciv embriyosunda yüksek dozda bile nöral tüp defekti gelişimi üzerine etkisi olmadığını göstermiştir.

ANAHTAR SÖZCÜKLER: Tavuk embriyosu, Gıda katkıları, Nöral tüp defekti, Sodyum benzoat

\section{INTRODUCTION}

Neural tube defects (NTD) are congenital malformations of the central nervous system and they occurred as a result of incomplete closure of the neural tube in between the 3rd and 4 th weeks of pregnancy $(1,8)$. The worldwide incidence of NTD ranges from 1.0 to 10.0 per 1000 births (8). Of 300 children that are born every year with NTD, survivors remain with lifelong disability (10).

Food additives were used to store food for long periods. They were also used for their effects on the appearance of the food and flavors.There is no significant nutritive value of food additives. However they are often used during the 
preparation and storage of foods, including antioxidants, food preservatives, food coloring agents, flavoring agents, anti-infective agents (10).

Preservetive additives are used to inhibit to growth of bacteria and yeasts in food. Thus, they prevent food spoilage and molding.

They can cause cancer, birth defects, genetic defects, brain damage, hyperactivity and attention deficit disorder, liver and kidney failure, high blood pressure, stroke, heart attack skin rashes, asthma, nausea and diarrhea (10). Sodium benzoate (SB) is a white solid and it is very soluble in the water. It is a widely used as a food preservative, with E number E211. Preservatives are used in many fields such as personal care and food products as well as pharmaceuticals. In this study, we aimed to evaluate the effects of sodium benzoate on neural tube defects in chicken embryos.

\section{MATERIAL and METHODS}

\section{Dosage of Sodium Benzoate}

Dosage calculation was made based on a provisional tolerable intake of SB is $5 \mathrm{mg} / \mathrm{kg}$ body weight per day, mentioned in the literature (16). Doses were calculated as Group A: $5 \mathrm{mg} /$ kg, Group B: $10 \mathrm{mg} / \mathrm{kg}$, Group C: $20 \mathrm{mg} / \mathrm{kg}$, Group D: 200mg/ kg. Sodium benzoate (C7H5NaO2, BioUltra, 71295-50G, Sigma) was dissolved in sterile distilled water to the desired concentrations. Incubation and injection of chicken embryos Fertile, specific pathogen free eggs were used (Bornova Veterinary Control and Research Institute, Izmir-Turkey).

\section{Incubation and Injection of Chicken Embryos}

The mean weight of the eggs was $65 \pm 2 \mathrm{~g}$. They were incubated for 30 hours at $60 \%$ to $70 \%$ humidity and $37.2 \pm 0.1$ ${ }^{\circ} \mathrm{C}$ temprature. Position was changed on its axis every 3 hours for each egg.) The study consisted of five groups. Each group contained 12 embryos. After 30 hours of incubation, the eggs were in stage 9 according to Hamburger-Hamilton series $(7,12)$. Egg shells were opened (under $4 x$ magnifications) and then embryonic discs were identified. $0.1 \mathrm{ml}$ previously prepared fluid was administered into each egg under their embriyonic discs. Injection was performed via a 24-gauge syringe. Group A: $0.33 \mathrm{mg} / 0.1 \mathrm{ml}$, Group B: $0.65 \mathrm{mg} / 0.1 \mathrm{ml}$, Group C: $1.30 \mathrm{mg} / 0.1 \mathrm{ml}$, Group D: $13.00 \mathrm{mg} / 0.1 \mathrm{ml}$ of SB was administered. Group E (control group): only $0.1 \mathrm{ml}$ of saline was injected. Sterile adhesive strip was used for covering opened egg shell. Eggs were incubated for 72 hours. At the end of the 72 nd hour eggs were reopened and embryos were dissected from embryonic membranes. Embryos were evaluated macroscopically and histopathologically. The embryo viability, general physiological condition and embryonic vasculature were examined macroscopically. Neural tube development was evaluated histopathologically.

\section{Histopathological Evaluation}

After dissection of embryos from embryonic membranes, tissue processing was started. Embryos were fixed in formol- acetic acid for 2 hour. Each embryo was dehydrated using a graded ethanol series (70\%, 95\%, and $100 \%)$ for 15 minutes and later cleard in xylene, before being embedded in paraffin (11). Paraffin blocks were cut into $5 \mu \mathrm{m}$ serial sections and mounted on glass slides. The slides were then deparaffinized in xylene and washed in a decreased ethanol gradient, before being stained hematoxyline-eosine.

\section{Statistical Analysis}

Data analyzed with Chi-square test. Probability values $p<0.05$ were considered to indicate significant difference. SPSS 16 software was used for analysis. All data were evaluated in a blinded fashion.

\section{RESULTS}

Embryo heartbeat were not found in two of each Groups $A, D, E$ and six in Group C during the dissection (Figure 1E). Mortality rate was not statistically significant between the groups (Chi-Square $=7.3535, \mathrm{df}=4, \mathrm{p}=0.1183$ ). When embryos were examined for the embryonic vasculature, membranes and the general physiological condition, we could not observed differences between the groups (Figure 1A-E). Wing buds of embryos were symmetric, leg buds were asymmetric and rotations were completed. We found that development of all the embryos were consistent with their stages. We detected the neural tube obstruction in one embryo in Group $C$ under microscopic examination (Figure 2F) ( $p>0.05$ ). Neural tube defects were not detected in all embryos groups (Figure $2 \mathrm{~A}-\mathrm{F})$.

\section{DISCUSSION}

The best known risk factor for fetal NTD is maternal folate deficiency $(1,8)$. Other risk factors for NTD development include a positive family history, smoking and air pollution $(3,10)$. Additionally NTDs may be related to maternal socioeconomic and socio-cultural status as well as to physical condition (1, 2). Many studies have been done on chicken embryos to investigate the etiology of NTD. They evaluated effects of environmental factors and drugs $(4,5,6,12,13,15)$.

With advent of processed food production, various food additives were introduced into our lives (10). Food additives are verg big family and they include; acids, acidity regulators, food coloring, emulsifiers, flavors, flavor enhancers, humectants, tracer gases, preservatives, stabilizers, sweeteners, thickeners, antioxidants, anticaking, antifoaming, bulking, glazing and color retention agents (10).

Another preservative is sodium benzoate mostly used for food, fruit juices, and soft drinks that are naturally in an acidic $\mathrm{pH}$ range.

The estimated global production capacity for benzoic acid is about 600000 tons per year. Due to the intensive usage of SB in our daily lives, we sought to assess its impact on development over the neural tube in chicken embryo. The acute oral toxicity of SB was found low (oral LD50 values of $>1940 \mathrm{mg} / \mathrm{kg}$ body weight) in rodents (16). Sodium benzoate's 

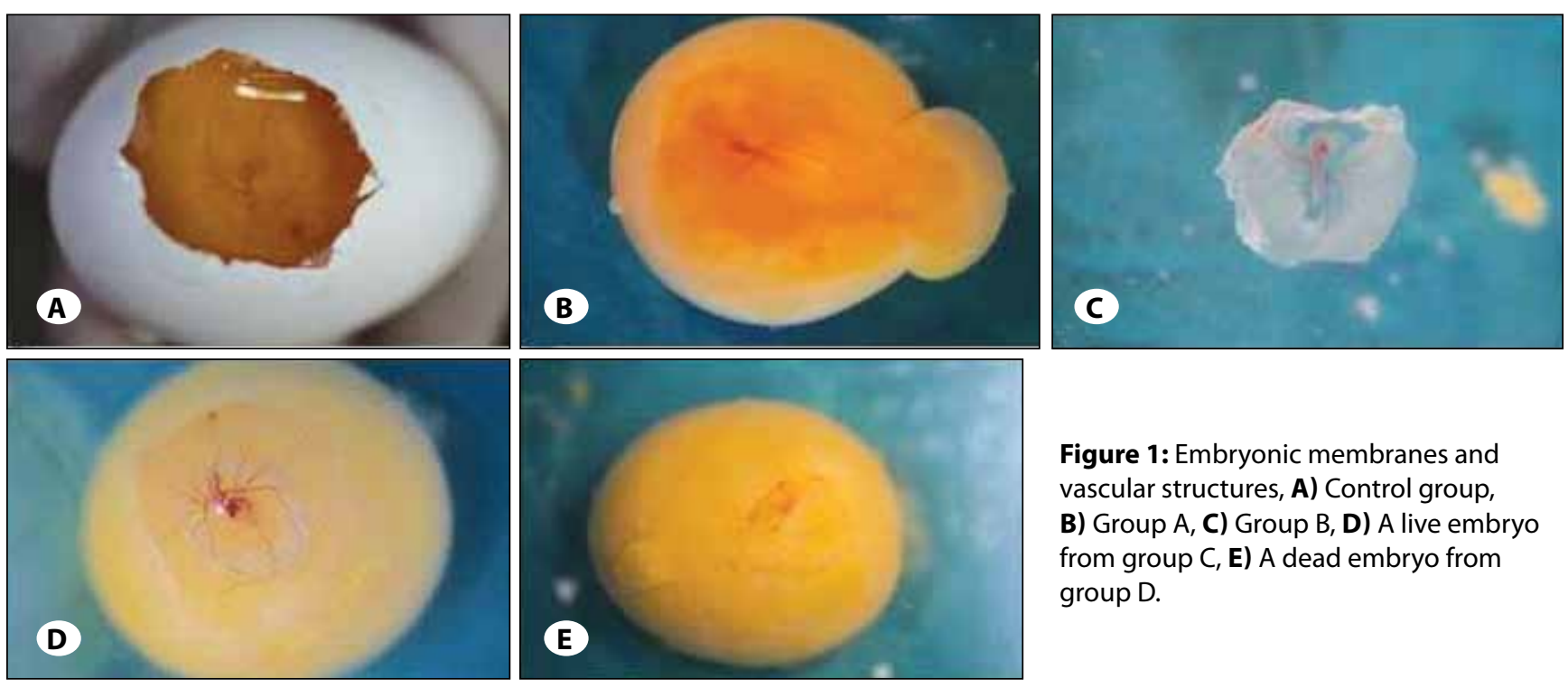

Figure 1: Embryonic membranes and vascular structures, A) Control group, B) Group A, C) Group B, D) A live embryo from group $C, E)$ A dead embryo from group D.
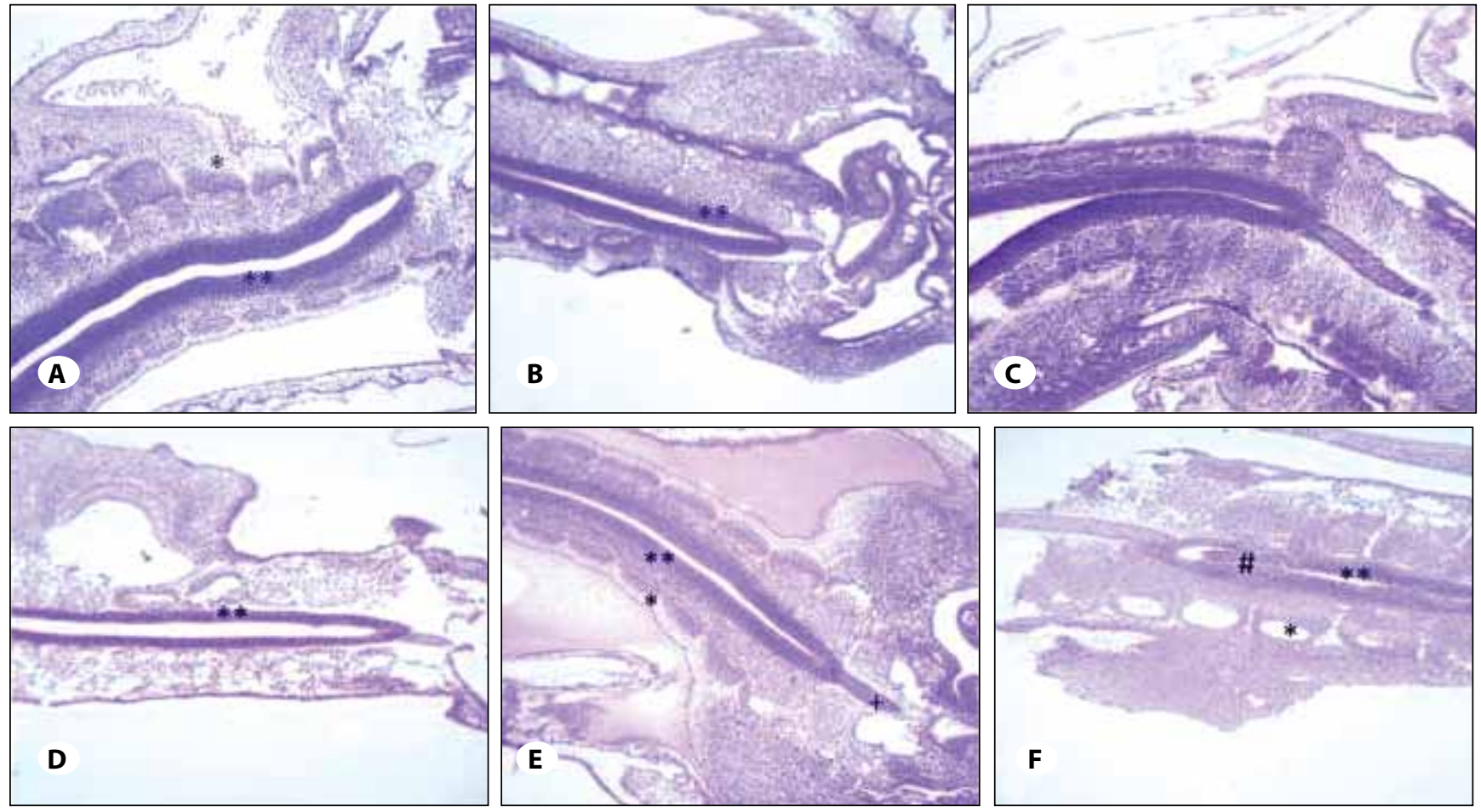

Figure 2: A) Group A, B) Group B, C) Group C, D) Group D, E) Control group, F) Neural tube obstruction in one embryo in Group ( under microscopic examination. 10x, Hematoxylin\&Eosin, *: Somite, **: Neural tube, +: Notochord, \#: Neural tube obstructions.

toxic effects and mortality were reported at much lower doses (about $450 \mathrm{mg} / \mathrm{kg}$ body weight) in cats $(3,16)$. Cats seem to be more sensitive than rodents. Sodium benzoate was not irritative to skin, except for a slight local reaction in the eye. In short-term studies with rats, higher doses with 1800 $\mathrm{mg} / \mathrm{kg}$ per body weight and longer duration of exposure contributed to disorders of the central nervous system with remarkable histopathological changes in the brain (16). Other effects included reductions in the overall weight of the whole body, biochemical and histopathological changes in the liver.
Carcinogenic effect of SB was not encountered in rats and mice in long-term studies (16). However, the documentation of effects of SB lacks in the literature.

In humans, the acute toxicity of benzoic acid and sodium benzoate is low. A provisional tolerable intake of SB is $5 \mathrm{mg} /$ $\mathrm{kg}$ body weight per day. Clinical signs of intoxication in rats included diarrhea, muscular weakness, tremors, hypoactivity (16). Tsay et al. (14) generated a series of time- and dosedependent SB exposure experiments on wild type zebrafish 
embryos. The muscle fibers alignment, kidney formation and motor neurons processing were examined in their study. Wild type zebrafish embryos were exposed in water or in water containing 10, 100, 500 and 1000ppm of SB for $24 \mathrm{~h}$. No significant differences in the survival rates between control group and low-dosages-treated groups were seen. However, they found that the survival rates decreased as the exposure time and the concentration of starting from 1100 to $1900 \mathrm{ppm}$ SB increased. They observed that SB exposure resulted in dosedependent defects of gut abnormalities, malformation of pronephros and edema in the pericardial sac. Also SB-induced motor defects was found dose depended and the range of 10-100 ppm. They determined that SB has no negative effects on somite boundary formation. The muscle fiber was innerved functionally by motor axons in both control and 10 ppm SB-treated groups. Similar results were observed but became more severe with increased dosages. They proposed that the SB-induced neurotocixities in zebrafish embryos are irreversible. Congruent to their findings, somite formation and alignment was normal in our study too, although dosage of SB which was administered extremely higher than that in our study. Tsay el al. (14) investigated neurotoxicity via monoclonal antibody labeling system. We examined the embryos histopathologically. Bateman et al. (2) reported that removal of the artificial colorings and SB from the diet of preschool children resulted in reduction in hyperactive behavior. Additionally, motor impairment and anxiety was detected in the SB administered rats in other study (9). Another important point to be considered; SB combines with ascorbic acid in some beverages. Decarboxylation of the SB yields a carcinogen product, benzene in the presence of ascorbic acid. It can cause permanent damage to organic tissues (16). Even though we could not identify neural tube defects in all embryos, we should be careful about beverages that include both ascorbic acid and SB. In our study, we observed no differences between the general physiological statuses of the embryos; symmetric wing buds, asymmetric leg buds were found and rotations were completed. We detected no neural tube defects in all embryos. Neural tube obstruction was observed in one embryo in group $C$. In group $D$, showed death rate higher than that in the other groups which was administered 40 times higher than the recommended daily dose, although this result was not statistically significant.

\section{CONCLUSION}

In the developing world, chemical additives' rate is increasing in our foods day by day. This situation was found to be confusing. This study showed that sodium benzoate, one of the widely used food preservatives, has no effect on neural tube defect development in chick embryo even at high doses.

\section{ACKNOWLEDGEMENTS}

Special thanks to Dr. Hakan Simsek for his kind technical support.

\section{REFERENCES}

1. Au KS, Ashley-Koch A, Northrup H: Epidemiologic and genetic aspects of spina bifida and other neural tube defects. Dev Disabil Res Rev 16:6-15, 2010

2. Bateman B, Warner JO, Hutchinson E, Dean T, Rowlandson P, Gant C, Grundy J, Fitzgerald C, Stevenson J: The effects of a double blind, placebo controlled artificial food colourings and benzoate preservative challenge on hyperactivity in a general population sample of preschool children. Arch Dis Child 89:506-511, 2004

3. Bedford PGC, Clarke EGC: Experimental benzoic acid poisoning in the cat. Veterinary record 90:53-58, 1972

4. Cetinkal A, Colak A, Topuz K, Demircan MN, Simsek $H$, Berber U, Umur AS, Selcuki M, Vatansever HS: The effects of meloxicam on neural tube development in the early stage of chick embryos. Turk Neurosurg 20:111-116, 2010

5. Dalgic A, Armağan E, Helvacioglu F, Okay O, Daglioglu E, Take G, Unlu A, Belen D: High dose cotinine may induce neural tube defects in a chick embryo model. Turk Neurosurg 19:224-229, 2009

6. Guvenc Y, Dalgic A, Billur D, Karaoglu D, Aydin S, Daglioglu E, Ozdol C, Nacar OA, Yildirim AE, Belen D: The effects of levetiracetam on neural tube development in the early stage of chick embryos. Turk Neurosurg 23:617-622, 2013

7. Hamburger V, Hamilton HL: A series of normal stages in the development of the chick embryo. J Morph 88:49-92, 1951

8. Lo A, Polšek D, Sidhu S: Estimating the burden of neural tube defects in low- and middle-income countries. J Glob Health 4:010402, 2014

9. Noorafshan A, Erfanizadeh M, Karbalay-Doust S: Sodium benzoate, a food preservative, induces anxiety and motor impairment in rats. Neurosciences (Riyadh) 19:24-28, 2014

10. Pandey RM, Upadhyay SK: Food additive. In: El-Samragy $Y$ (ed), Food Additive. http://www.intechopen.com/books/ food-additive/food-additive 1-30, 2012

11. Schoenwolf GC: Effects of complete tail bud extirpation on early development of the posterior region of the chick embryo. Anat Rec 192:289-296, 1978

12. Simsek H, Colak A, Kaya S, Kutlay M, Cetinkal A, Haholu A, Demircan MN: The effects of Diesel exhaust particles on neural tube development in the early stage chicken embryo. Turk Neurosurg 22:77-82, 2012

13. Temiz C, Temiz P, Demirel A, Sayin M, Umur AS, Ozer FD: Effect of sodium phenytoin concentration on neural tube development in the early stages of chicken embryo development. J Clin Neurosci 16:307-331, 2009

14. Tsay HJ, Wang YH, Chen WL, Huang MY, Chen YH: Treatment with sodium benzoate leads to malformation of zebrafish larvae. Neurotoxicol Teratol 29:562-569, 2007

15. Whitsel Al, Johnson CB, Forehand CJ: An in ovo chicken model to study the systemic and localized teratogenic effects of valproic acid. Teratology 66:153-163, 2002

16. Wibbertmann A, Kielhorn J, Koennecker G, Mangelsdorf I, Melber C: Concise International Chemical Assessment Document 26: Benzoic Acid and Sodıum Benzoate, Fraunhofer Institute for Toxicology and Aerosol Research, World Health Organization Geneva. Wissenschaftliche Verlagsgesellschaft $\mathrm{mbH}, \mathrm{D}-70009$ Stuttgart 10, 2005: 1-48 